This item was submitted to Loughborough's Research Repository by the author.

Items in Figshare are protected by copyright, with all rights reserved, unless otherwise indicated.

\title{
Growth of nanomaterials in construction raises health and safety concerns
}

PLEASE CITE THE PUBLISHED VERSION

http://dx.doi.org/10.1680/cien.2014.167.2.51

\section{PUBLISHER}

ICE Publishing Ltd. @ Thomas Telford Ltd.

\section{VERSION}

VoR (Version of Record)

\section{LICENCE}

CC BY-NC-ND 4.0

\section{REPOSITORY RECORD}

Walker, Graeme, Roger Ball, and Alistair G.F. Gibb. 2019. "Growth of Nanomaterials in Construction Raises Health and Safety Concerns". figshare. https://hdl.handle.net/2134/21394. 


\title{
Growth of nanomaterials in construction raises health and safety concerns
}

\author{
The increased use of engineered nanomaterials in the construction industry - particularly in exciting \\ innovative materials and products - raises the spectre of another asbestosis crisis. Graeme Walker, \\ Roger Ball and Alastair Gibb of the ICE health and safety expert panel report.
}

Nanotechnology has been revolutionising our lives over the last decade or so. It involves the creation and/or manipulation of materials at the nanometre $(\mathrm{nm})$ scale to improve their characteristics - particularly strength, durability and serviceability.

\section{Construction applications}

The construction industry is no exception. Engineered nanoparticles can now be found in a wide range of construction materials and products, usually embedded in a base material, and new applications are appearing almost monthly.

Examples include self-healing concrete, high-strength composites, corrosionresistant reinforcement, high-strength bolts, fire protection, solar panels, water filters, aerogel insulation, ceramics, antirust sprays, stone and timber protection sprays, sealants, special mortars, and selfcleaning glass

However, when such materials are subject to activities such as cutting, drilling or abrasion - or, in the case of fluids, spraying - the nanoparticles may be freed and ingested by people. As the construction industry is well aware, not all construction dust is benign.

\section{Potential health risks}

Several research projects have investigated the short- and long-term health and environmental implications of nanoparticles.

A report by the Royal Society of Chemistry in 2011 stated that though there have been few studies of the longterm consequences of nanoparticles on human health, questions have been raised of whether seemingly innocuous nanoparticle-containing materials should be treated with the same caution

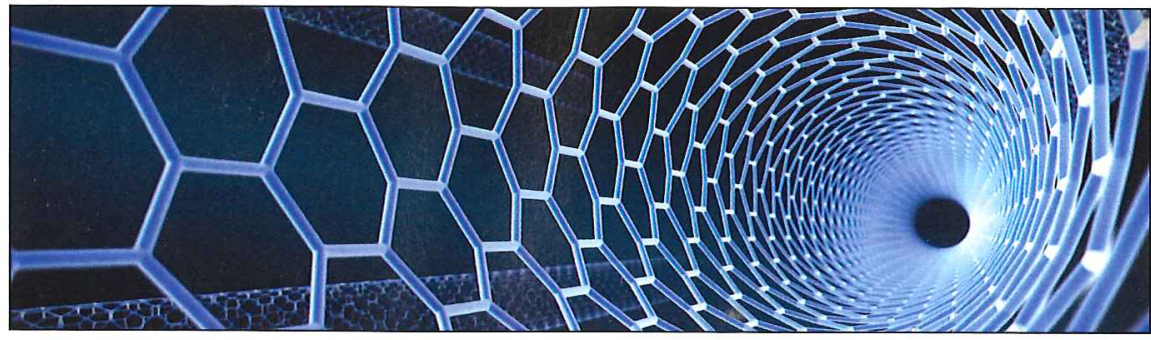

Carbon nanotubes are currently used in epoxy resins to make high strength composites and paints, but are they safe? (courtesy daniel700 / Fotolia)

afforded known carcinogens such as asbestos (Sharifi et al., 2012).

Indeed, a major study published in Nature Nanotechnology (Poland et al., 2008) suggests some forms of nanoparticles could be as harmful as asbestos if inhaled in sufficient quantities. Co-author Anthony Seaton of the Institute of Occupational Medicine in Edinburgh said, 'We know that some of them probably have the potential to cause mesothelioma...so those sorts of materials need to be handled very carefully.'

\section{Precautionary approach}

The UK Health and Safety Executive (HSE) publication HSG272, Using nanomaterials at work, states that, 'in view of the evidence for lung damage and lack of information on the effects of longterm repeated exposure, a higher level of control is warranted' (HSE, 2013: p. 5).

While there are currently no UK statutory workplace exposure limits specifically for nanomaterials, the HSE recommends that a precautionary approach should be taken to risk management.

Applying the precautionary principle is essentially a matter of making assumptions about consequences and likelihoods to establish credible scenarios, and then using standard procedures of risk assessment and management to inform decisions on how to address the hazard or threat.

\section{Advice for civil engineers}

In order to demonstrate best practice and prudence, all professional civil engineers should therefore carry out a control of substances hazardous to health $(\mathrm{COSHH})$ risk assessment on construction products and materials believed to contain nanomaterials.

A list should be made of the actions taken to control the risks to health, including steps taken to identify the risk, how that possible risk to health is being controlled and how this will be reviewed.

A suitable $\mathrm{COSHH}$ assessment form is available on the HSE nanotechnology website at http://www.hse.gov.uk/ nanotechnology/index.htm.

\section{References}
HSE (Health and Safety Executive) (2013) Using Nanomaterials at Work, HSG272. The Stationery Office, Norwich, UK. See http://www.hse.gov.uk/ pubns/books/hsg272.pdf (accessed 12/03/2014).
Poland CA, Duffin R, Kinloch I et al. (2008) Carbon nanotubes introduced into the abdominal cavity of mice show asbestos-like pathogenicity in a pilot study. Nature Nanotechnology 3(7): 423-428.
Sharifi S, Behzadi S, Laurent S et al. (2012) Toxicity of nanomaterials. Chemical Society Reviews 41(6): 2323-2343. See http://pubs.rsc.org/en/cont
articlelanding/2012/cs/c1cs15188f (accessed 12/03/2014).

